\title{
EVALUATION AND ATTITUDE OF PHARMACY STUDENTS TOWARDS DRUG INFORMATION COURSES
}

\author{
M. N. Al-Arifi \\ College of Pharmacy, King Saud University, Riyadh, Saudi Arabia

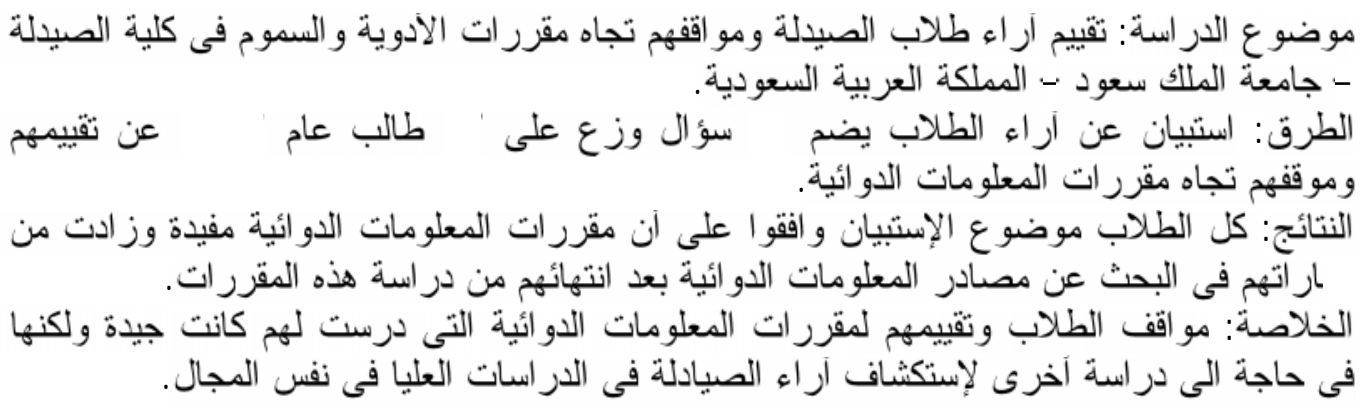

Objective:Assessment of the pharmacy students' opinions and attitudes towards the drug and poison information courses at college of pharmacy, King Saud University.

Method: Self-administered questionnaire containing 12 items was distributed to 43 pharmacy students at college of pharmacy, King Saud University at Riyadh City, year 2007 about their evaluation and attitudes towards drug information courses.

Results: all respondents agreed that the drug information courses are useful and their skills in searching various drug information resources were increased after they finished the courses.

Conclusion: The attitude and evaluation of the students for drug information courses that had been taught to them was good, but there is need for further studying this subject by exploring the opinion of graduate pharmacists in the work field.

\section{INTRODUCTION}

Drug information services have evolved as a result of enormous information explosion over the past decades. The importance of drugs in clinical therapy promoted the development of drug information centers to assist the healthcare team and keep them well informed with the modern trend in drug therapy ${ }^{1-3}$.

Since operating of the first formalized drug information at the Kentucky University in 1962, many formal drug information centers have been developed throughout the United States $^{4}$ and Europe ${ }^{5}$ to provide accurate and timely information in response to specific drugrelated questions. As vital members of the health care team, pharmacists are involved in drug therapy decisions. Physicians, nurses, and other health professionals realize the pharmacist's role as a provider of drug information and often, the frequency of utilization of the pharmacist depends on his ability to successfully search the literature and provide reliable information. In addition, today's patients are demanding that the pharmacist provide more information about drug effects and potential adverse reactions. Due to the changing role of the pharmacist and the increasing demand for drug information by fellow health professionals, and the general public, it is important that pharmacy students be given an opportunity to acquire the knowledge of how to utilize the available medical literature. Specifically, the students need to understand how to select appropriate literature sources; be able to critically evaluate the literature; and finally be able to apply this information to patient care. This knowledge will not only provide a foundation for the drug information skills required for a pharmacist but it may also enhance and simplify other pharmacy course work ${ }^{6}$

As a consequence of this, the drug and poison information center (DPIC), the first of 
its kind in the Kingdom of Saudi Arabia, was established on the late 1979s at the college of pharmacy, King Saud University ${ }^{7}$ and since that time similar centers have been developed and increasingly grown in number and sophistication to encompass approximately all major hospitals in the Kingdom ${ }^{8}$.

Reports on the daily activities of drug and poison information centers within the hospitals and the needs for such centers has been well documented $^{9-12}$. However, little information is available on the activities and need for college of Pharmacy based drug and poison information centers $^{13}$. The objective of this study is to assess the pharmacy students' opinion and attitude towards the drug and poison information courses.

\section{Description of the center}

The College of Pharmacy drug and poison information center (DPIC) at King Saud University contains numerous textbooks, journals, the Iowa Drug Information Service, Micromedex as well as an access to the Internet.

The DPIC is intended to provide drug information services and consultation to health care professionals and to the community via telephone and written responses ${ }^{6}$ throughout the kingdom and from outside the kingdom, particularly the Gulf region. Apart from handling drug inquiries it also publishes a newsletter on a bimonthly basis that gives information on new drugs, drug reactions and interactions as well as market news. The newsletter is distributed to the health professionals inside and outside the Kingdom. Also, the DPIC participates in research activities pertaining to drug and poison information centers and their developments in Saudi Arabia. In addition, the DPIC provides drug information services to undergraduate and postgraduate students and the college staff and also as a laboratory for teaching pharmacy students the techniques of drug information retrieval, evaluation, analysis and dissemination of drug and poison information in two separate courses ${ }^{12}$. The first course (PHCL 451, introduction to drug information services) was designed to provide a detailed review of process of providing drug information using systematic approach of retrieval. The students should gain experience in utilizing indexing abstracting services such as IDIS and Medline. Furthermore the students will be given assignments that provide hand-on experience in drug evaluation, book evaluation and in locating drug information and preparing written responses. The second course (PHCL 456, literature evaluation) provides the students with the necessary experience in literature evaluation and dissemination of drug and poison information.

\section{Methodology}

The study included questions about the educational responsibilities provided by the DPIC. A two page self-administered questionnaire containing 12 attitudinal statements was developed (Tables 1-4), and handled to 43 students who have just completed the two courses of drug and poison information. The performance, improving skills and usefulness of the courses, adequacy in preparation to assume practice and impact of the course to pharmacy practice as today and in the future consisted of 4,1,1,3 and 3 statements, respectively. The respondents were asked to report their gender, age, level of education, work setting, their job-title and marital status. They were also asked to indicate whether they agreed or disagreed with each of 12 statements using a 5-point likert scale (1= strongly disagree and $5=$ strongly agree). Also they were asked to indicate whether the courses are useful or useless in one statement using 5-point likert scale $(1=$ useless and $5=$ very useful). Furthermore, to indicate their improved skills in retrieving information resources since they finished the courses, respondents were presented with 5 points Likert scale where $1=$ greatly decreased and 5= greatly increased.

Statistical analysis was made to describe the properties of the sample in terms of frequencies and distribution using the Statistical Packages for the Social Science (SPSS) Program.

\section{RESULTS AND DISCUSSION}

\section{Results}

Thirty four questionnaires out of 43 originally distributed were collected to assess the attitudes and evaluate the drug information courses by pharmacy students, college of pharmacy, King Saud University, with 
response rate of $79 \%$. As shown in the tables most answers of the respondents, that they benefited from the drug information courses, so in the gradual scale $26.5 \%$ of the respondents choose number 5 and $44.1 \%$ had chosen number 4.

The opinion of respondents towards 12 attitudinal statements about the courses is summarized in Tables 1-4. The results of the study showed that the majority of respondents perceived the course as useful (score of 5 was assigned to $26.5 \%$, and 4 to $44.1 \%$ of the responses), and it increases their searching capability and skills through various indexing and abstracting systems (score of 5 was assigned to $23.5 \%$ and 4 to 61.7 of the responses). Furthermore, on the scale of 1 (strongly disagree) and 5 (strongly agree), respondents stated that they were able to utilize various electronic databases and perform their own search without the help of others, (a score of 5 was assigned to $44.1 \%$ of responses and 4 assigned to $35.3 \%$ of responses), while if the student is unable to do this without the help of others before taken the course (a score of 5 was assigned to $26.5 \%$ of responses and 4 assigned to $44.1 \%$ of responses). Also, the majority of the respondents (a score of 5 was assigned to $50.0 \%$ of responses and 4 assigned to $20.6 \%$ of responses) prefer that the course PHCL 451 to be given early during the years of study. When the respondents were asked whether they were adequately prepared to assume practice in DPIC, analyze and evaluate scientific literature, $14.7 \%$ and $28.8 \%$ of respondents strongly agreed and agreed that they were adequately prepared to assume practice in the DPIC, respectively, whereas, $32.4 \%$ strongly agreed and $26.4 \%$ agreed that they feel that they were adequately prepared to carry out analysis and evaluation of scientific literature when the matter is concerned with answering a question. Furthermore, $35.3 \%$ strongly agreed and $38.2 \%$ agreed that they were adequately prepared to perform program pertaining to DPIC in their practice settings. Moreover, when respondents were asked whether the courses are an excellent preparation for practice of pharmacy in general, particularly, in the area of drug consultation, the majority viewed the courses as an excellent preparation for practice of pharmacy today, (a score of 5 was assigned to $44.1 \%$ of responses and 4 assigned to $47.1 \%$ of responses) and for practice of pharmacy in the future, a score of 5 was assigned to $50.0 \%$ of responses and 4 assigned to $32.4 \%$ of responses, whereas, $35.3 \%$ strongly agreed and $38.2 \%$ agreed that the courses are an excellent preparation to keep abreast of changes in the area of consultation for the years to come.

Table 1: Attitude of the new graduates towards the course PHCL 451.

\begin{tabular}{|c|c|c|c|c|c|c|}
\hline Reaction & $\begin{array}{c}\text { Strongly } \\
\text { agree }\end{array}$ & Agree & Uncertain & Disagree & $\begin{array}{l}\text { Strongly } \\
\text { disagree }\end{array}$ & $\begin{array}{c}\text { Average } \\
\text { score }\end{array}$ \\
\hline $\begin{array}{l}\text { Before taking the course, I was } \\
\text { unable to perform search for my } \\
\text { information in the DPIC without } \\
\text { the help of others }\end{array}$ & $\begin{array}{c}9 \\
(26.5 \%)\end{array}$ & $\begin{array}{c}15 \\
(44.1 \%)\end{array}$ & $\begin{array}{c}6 \\
(17.6 \%)\end{array}$ & $\begin{array}{c}3 \\
(8.8 \%)\end{array}$ & $\begin{array}{c}1 \\
(1.9 \%)\end{array}$ & 4 \\
\hline $\begin{array}{l}\text { After finishing the course I was } \\
\text { able to perform my search } \\
\text { without the help of others }\end{array}$ & $\begin{array}{c}11 \\
(32.4 \%)\end{array}$ & $\begin{array}{c}13 \\
(38.2 \%)\end{array}$ & $\begin{array}{c}5 \\
(14.7 \%)\end{array}$ & $\begin{array}{c}5 \\
(14.7 \%)\end{array}$ & $\begin{array}{c}5 \\
(14.7 \%)\end{array}$ & 4 \\
\hline $\begin{array}{l}\text { I feel adequately prepared to } \\
\text { search electronic databases and } \\
\text { tertiary resources }\end{array}$ & $\begin{array}{c}15 \\
(44.1 \%)\end{array}$ & $\begin{array}{c}12 \\
(35.3 \%)\end{array}$ & $\begin{array}{c}5 \\
(14.7 \%)\end{array}$ & $\begin{array}{c}1 \\
(2.9 \%)\end{array}$ & $\begin{array}{c}1 \\
(2.9 \%)\end{array}$ & 4 \\
\hline $\begin{array}{l}\text { The course is very useful, and in } \\
\text { my opinion should be given early } \\
\text { in the years of the study }\end{array}$ & $\begin{array}{c}17 \\
(50.0 \%)\end{array}$ & $\begin{array}{c}7 \\
(20.6 \%)\end{array}$ & $\begin{array}{c}4 \\
(11.8 \%)\end{array}$ & $\begin{array}{c}5 \\
(14.7 \%)\end{array}$ & $\begin{array}{c}1 \\
(2.9 \%)\end{array}$ & 4.5 \\
\hline
\end{tabular}


Table 2: Attitude of the newly graduates toward the two courses.

\begin{tabular}{|c|c|c|c|c|c|c|}
\hline Reaction & Useless & No use & Neutral & Useful & $\begin{array}{c}\text { Very } \\
\text { useful }\end{array}$ & $\begin{array}{c}\text { Average } \\
\text { score }\end{array}$ \\
\hline $\begin{array}{l}\text { At the moment how useful } \\
\text { do you find the courses }\end{array}$ & $\begin{array}{c}3 \\
(8.8 \%)\end{array}$ & $\begin{array}{c}3 \\
(8.8 \%)\end{array}$ & $\begin{array}{c}4 \\
(11.8 \%)\end{array}$ & $\begin{array}{c}20 \\
(58.8 \%)\end{array}$ & $\begin{array}{c}4 \\
(11.8 \%)\end{array}$ & 4 \\
\hline & $\begin{array}{l}\text { Strongly } \\
\text { decrease }\end{array}$ & decrease & The same & increase & $\begin{array}{l}\text { Strongly } \\
\text { increase }\end{array}$ & $\begin{array}{c}\text { Average } \\
\text { score }\end{array}$ \\
\hline $\begin{array}{l}\text { How would you rate your } \\
\text { skill in using indexing } \\
\text { abstracting systems, since } \\
\text { you fished the courses }\end{array}$ & & $\begin{array}{c}3 \\
(8.8 \%)\end{array}$ & $\begin{array}{c}2 \\
(5.8 \%)\end{array}$ & $\begin{array}{c}21 \\
(61.7 \%)\end{array}$ & $\begin{array}{c}8 \\
(23.5 \%)\end{array}$ & 4 \\
\hline
\end{tabular}

Table 3: Attitude of the newly graduates toward the course PHCL 456.

\begin{tabular}{|l|c|c|c|c|c|c|}
\hline \multicolumn{1}{|c|}{ Reaction } & $\begin{array}{c}\text { Strongly } \\
\text { agree }\end{array}$ & Agree & Uncertain & Disagree & $\begin{array}{c}\text { Strongly } \\
\text { disagree }\end{array}$ & $\begin{array}{c}\text { Average } \\
\text { score }\end{array}$ \\
\hline $\begin{array}{l}\text { I feel adequately prepared to } \\
\text { assume practice in a drug } \\
\text { information center }\end{array}$ & $\begin{array}{c}5 \\
(14.7 \%)\end{array}$ & $\begin{array}{c}20 \\
(28.8 \%)\end{array}$ & $\begin{array}{c}8 \\
(23.5 \%)\end{array}$ & ----- & $\begin{array}{c}1 \\
(2.9 \%)\end{array}$ & 4 \\
\hline $\begin{array}{l}\text { I feel adequately prepared to } \\
\text { analyze and evaluate literature } \\
\text { articles. }\end{array}$ & $\begin{array}{c}11 \\
(32.4 \%)\end{array}$ & $\begin{array}{c}9 \\
(26.4 \%)\end{array}$ & $\begin{array}{c}11 \\
(32.4 \%)\end{array}$ & $\begin{array}{c}3 \\
(8.8 \%)\end{array}$ & ------ & 4 \\
\hline $\begin{array}{l}\text { I feel adequately prepared to } \\
\text { institute a program pertaining } \\
\text { to drug information resources }\end{array}$ & $\begin{array}{c}7 \\
(20.6 \%)\end{array}$ & $\begin{array}{c}13 \\
(38.2 \%)\end{array}$ & $\begin{array}{c}11 \\
(32.4 \%)\end{array}$ & $\begin{array}{c}2 \\
(5.9 \%)\end{array}$ & $\begin{array}{c}1 \\
(2.9 \%)\end{array}$ & 4 \\
\hline
\end{tabular}

Table 4: Attitude of new graduate to ward the pharmacy practice and in particular area of drug consultation.

\begin{tabular}{|l|c|c|c|c|c|c|}
\hline \multicolumn{1}{|c|}{ Reaction } & $\begin{array}{c}\text { Strongly } \\
\text { agree }\end{array}$ & Agree & Uncertain & Disagree & $\begin{array}{c}\text { Strongly } \\
\text { disagree }\end{array}$ & $\begin{array}{c}\text { Average } \\
\text { score }\end{array}$ \\
\hline $\begin{array}{l}\text { The drug information course is } \\
\text { an excellent preparation for } \\
\text { practice of pharmacy, in general, } \\
\text { particularly in area of drug } \\
\text { consultation, as it today }\end{array}$ & $\begin{array}{c}15 \\
(44.1 \%)\end{array}$ & $\begin{array}{c}16 \\
(47.1 \%)\end{array}$ & $\begin{array}{c}3 \\
(8.8 \%)\end{array}$ & ----- & ------ & 4 \\
\hline $\begin{array}{l}\text { The drug information course is } \\
\text { an excellent preparation for } \\
\text { practice of pharmacy, } \\
\text { particularly in area of drug } \\
\text { consultation. In the future }\end{array}$ & $\begin{array}{l}17 \\
(50.0 \%)\end{array}$ & $\begin{array}{c}11 \\
(32.4 \%)\end{array}$ & $\begin{array}{c}2 \\
(5.9 \%)\end{array}$ & $\begin{array}{c}2 \\
(5.9 \%)\end{array}$ & $\begin{array}{c}2 \\
(5.9 \%)\end{array}$ & 4.5 \\
\hline $\begin{array}{l}\text { The drug information course, is } \\
\text { an excellent preparation to keep } \\
\text { abreast of changes in area of } \\
\text { drug consultation in the years to } \\
\text { come }\end{array}$ & $\begin{array}{c}12 \\
(35.3 \%)\end{array}$ & $\begin{array}{c}(38.2 \%) \\
13\end{array}$ & $\begin{array}{c}5 \\
(14.7 \%)\end{array}$ & $\begin{array}{c}(5.9 \%) \\
2\end{array}$ & $\begin{array}{c}21 \\
(5.9 \%)\end{array}$ & 4 \\
\hline
\end{tabular}




\section{Discussion}

The primary goal of teaching drug and poison information courses is to prepare pharmacy students to be competent to practice in the designated area of information. It should not be surprising that there were differences in the level of agreement with the attitudinal statements across the respondents. In general, the study showed that agreement with all statements was significantly higher among the respondents, since the scores assigned for all statements were uniformly high with an

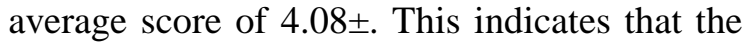
majority of the respondents viewed the courses as valuable and helpful, expanded their knowledge and have better impact on their ability to use various computerized databases. This finding may be supported by the high number $(70.6 \%)$ of the respondents who demanded the course, particularly PHCL 451, to be given in the early years of the study. Our results were in agreement with previous studies, as that conducted at the university of Michigan on third year pharmacy students, who were enrolled in drug information and scientific literature evaluation course and showed that the computer search system appears to have had an impact on the continued use of the computerized literature searching several years after the formal educational $\operatorname{program}^{14}$. Furthermore, a study of incorporation of internet databases into pharmacotherapy showed that the utilization of internet has become very important for clinicians, educators and researchers in pharmacy as well as in medicine ${ }^{15}$. Also a study in the university of Kentucky showed that a three primary new components of the model for teaching drug information includes teaching the course topics in an integrated manner throughout the curriculum, outlining practicebased outcomes for drug information throughout the curriculum, and impressing upon students that drug information skills are a vital part of routine pharmacy practice in the first, second and third professional years and the feedback from the faculty suggest that the first professional year students are able to integrate information better from several sources such as patient parameters and literature evidence and search for information independent of a scheduled assignment. Future plans include integration of second and third year outcomes into the curriculum, expand faculty development skills in the area of drug information, and maintain pharmaceutical care initiatives in the state of Kentucky for drug information skills ${ }^{16}$.

Although most of the respondents felt that the courses are useful and provide excellent preparation for practicing in the drug and poison information center, however few respondents mentioned negative or neutral emotional impact towards the courses.

\section{Conclusion and recommendation}

The attitude and evaluation of the students for drug information courses that had been taught to them was good, however, there is a need for studying this subject by exploring the opinion of graduate pharmacists in the work field which will enable the colleges of pharmacy to develop the teaching of drug information and scientific literature courses which will be reflected on the pharmaceutical care offered to patients in both general and private sectors.

\section{REFERENCES}

1- D. Burkholder, "Some Experiences in the Establishment and Operation of a Drug Information Center", Am. J. Hosp. Pharm., 20, 506-13 (1963).

2- R. P. Evens, "The State of Art and Future Directions of Drug Information Centers", Pharm. Int., 6, 74-7 (1985).

3- P. F. Parker, "The University of Kentucky Drug Information Center", Am. J. Hosp. Pharm., 22, $42-7$ (1965).

4- R. B. Varbel and A. B. Amerson, "Drug Information Centers, An Efficient Information Resource", Drug Ther., 6, 7580 (1976).

5- J. E. Markind and J. M. Stachnik, "European Drug Information Centers". J. Hum. Lact., 12, 239-42 (1996).

6- B. A. Mullins, R. P. D'Elia, C. L. Barnes and CM. Fleming, "Comparison of Drug Information Course Curricula in Schools and Colleges of Pharmacy", Am. J. Pharm. Educ., 59, 55-59 (1995).

7- A. M. Ageel, "Drug and Poison Information Center in the College of Pharmacy, University of Riyadh", First Drug Symposium in Saudi Arabia, College 
of Pharmacy, University of Riyadh, (1979).

8- M. N. Al-Arifi, S. Al-Madi, O. A. Gubara and M. H. Dana, "Survey of Drug Information Centers in Riayadh City Saudi Arabia", Arab Journal of Pharmaceutical Sciences, 2, 27-28 (2003).

9- D. M. Timm, K. M. Swartz and K. N. Amoh, "King Khalid University Hospital Drug and Poison Information Service, A Descriptive Report and Comparison with the University of Minnesota Drug Information Center", J. Pharm. Technol., 7, 179-83 (1991).

10- M. E. Joy, C. J. Arana and G. R.Gallo, "Use of Information Source at University Hospital Drug Information Service", Am. J. Hosp. Pharm., 43, 1226-9 (1986).

11- A. B. Fatah, A. B. Rahman and N. A. ABU Samah, "The Drug Information Service at A University Hospital in Malaysia: Characteristics of Drug Inquiries", Drug Inf. J., 32, 293-298 (1998).
12- F. Schneiweiss, "Activities of a College Based Drug Information Center", Drug Inf. J. 14, 72-76 (1980).

13- College of Pharmacy, King Saud University Bulletin, 54, 56 (1996).

14- N. R. Ikeda and D. G. Schwartz, "Impact of End-user Search Training on Pharmacy Students, A Four-year Follow-up Study", Bull. Med. Libr. Assoc., 80 (2), 124-130 (1992).

15- R. K. Sylvester, "Incorporation of Internet Databases into Pharmacotherapy Coursework", Am. J. Pharm. Edu., 61 (1), 50-55 (1997).

16- M. L. Gora-Harper and F. Barbara, "Brandt A. Needs Assessment for an External Doctor of Pharmacy Degree Program," Am. J. Pharm. Edu., 61 (3), 296-302 (1997). 